\title{
Genetic variances for dry matter yield, nitrogen content, and nitrogen yield in crested wheatgrass-alfalfa mixtures
}

\author{
K.H. ASAY AND H.F. MAYLAND
}

\section{Abstract}

Since its introduction from Asia in the early 1900s, crested wheatgrass [Agropyron cristatum (L.)Gaertner, A. desertorum (Fisch. ex Link) Schultes et al.] has had a major impact on the improvement of western rangelands of North America. Most of the early seedings with this cool-season grass were made as monocultures. Present and projected use of rangelands, however, prescribe that future crested wheatgrass cultivars have the genetic potential to be an effective component in a species complex including other grasses, shrubs, and forbs. The present study was conducted to evaluate the effect of associated alfalfa (Medicago sativa L.) on the performance and genetic variability in a 50-clone sample of a tetraploid crested wheatgrass breeding population. Significant $(P<0.05)$ differences were found among the clonal lines for dry matter (DM) yield, nitrogen (N), and $N$ yield. Opportunities for genetic improvement, as indicated by the magnitude of the genetic variation for these characters, was significantly increased when the grasses were grown in association with alfalfa. Significant $(P<0.01)$ and positive correlations of clonal means between stand types indicated that differences among the clonal lines in DM yield, $N$ content, and $\mathbf{N}$ yield were relatively consistent when grown with or without alfalfa. These results indicate that initial screening could be effectively done in tetraploid crested wheatgrass in the presence or absence of alfalfa. Final evaluation of breeding lines and experimental strains, however, should be done with alfalfa if the object is to develop cultivars to be grown in combination with that species.

Key Words: Agropyron cristatum, Agropyron desertorum, Medicago sativa, heritability, genotype by environment, grass breeding, nitrogen uptake, nitrogen transfer, nitrogen mineralization

The first successful introduction of crested wheatgrass [Agropyron cristatum (L.) Gaertner, A. desertorum (Fish. ex Link) Schultes, and $A$. fragile (Roth) Candargy] into North America was made in 1906 (Dillman 1946). It has since had more impact on revegetation of western rangelands in North America than any other grass. Most of the early crested wheatgrass seedings were made as monocultures; however, environmental concerns and multiple demands now made on rangelands dictate that other grass, shrub, and forb species be included in the seeding mix.

The beneficial effects of legumes on succeeding crops in a rotation is well documented (Lohnis 1926, Trenbath 1974, Heichel 1987). The positive contribution of nitrogen $(\mathrm{N})$ to this interaction was established in the early 1900s (Fred et al. 1932, Heichel 1987) and will likely have increasing economic impact as the availability of fossil fuels becomes more critical. The major benefits stemming from grass-legume mixtures are related to $\mathbf{N}$ transfer from the legume to associated grasses. Nitrogen is released from roots of the legume plant through active or passive release of soluble materials from intact cells, sloughing and decomposition of epidermal cells, lysis of cells by pathogens, and senescence of nodules and roots

\footnotetext{
Authors are research geneticist and research soil scientist, USDA-ARS, Logan, Utah 84322-6300 and Kimberly, Idaho 83341-9710, respectively.

Cooperative investigations of USDA-ARS and the Utah Agricultural Experiment Station, Logan, Utah 84322. Approved as Journal Paper No. 4045. The authors acknowledge the technical assistance provided by W.T. Hansen, G.E. Shewmaker, and S.B. Hansen.

Manuscript accepted 16 December 1990.
}

(Brophy and Heichel 1989). Nitrogenous compounds secreted into the surrounding soil medium consist of ammonia, glutamate, serine, alanine, and aspartate (Ta et al. 1986).

Brophy and Heichel (1989) studied net $\mathrm{N}$ release from actively growing root systems of alfalfa (Medicago sativa L.) and soybeans (Glycine $\max$ L. Merr.) in an enclosed root chamber containing sterile sand medium. Alfalfa plants inoculated with an adapted rhizobial strain and irrigated with $\mathrm{N}$-free nutrient solution released $4.5 \%$ of symbiotically fixed plant $\mathrm{N}$ into the root zone from 85 to 173 days after germination. In these studies, release of $N$ from alfalfa roots was increased by shoot harvest and periodic water stress. In greenhouse trials, Ta and Faris (1987) found that yields of herbage and protein were significantly increased in 5 perennial forage grasses when grown in association with alfalfa, red clover (Trifolium pratense L.), and birdsfoot trefoil (Lotus corniculatus L.) compared to grasses in monoculture.

In Switzerland, Boller and Nosberger (1987) studied symbiotic production of $\mathrm{N}$ in white clover (Trifolium repens L.) and red clover when grown in association with perennial ryegrass (Lolium perenne L.) and Italian ryegrass (Lolium multiflorum Lam.), respectively. Annual yield of clover $\mathbf{N}$ derived from symbiosis averaged $131 \mathrm{~kg} \mathrm{ha}^{-1}$ and $308 \mathrm{~kg} \mathrm{ha}^{-1}$ during the seeding year and first production year, respectively. The apparent clover-to-grass transfer to fixed $\mathrm{N}$ contributed up to $52 \mathrm{~kg} \mathrm{~N} \mathrm{ha}^{-1}$ to the $\mathrm{N}$ yield of the mixtures. Symbiotic $\mathrm{N}$ yield levels were decreased an estimated 25 to $35 \%$ by fertilization with supplemental $\mathrm{N}$.

Brophy et al. (1987) reported that significant amounts of $\mathrm{N}$ were transferred from alfalfa and birdsfoot trefoil to reed canarygrass (Phalaris arundinacea L.) under field conditions. Although the amount of $\mathbf{N}$ transferred was dependent on interspecies distance and legume/grass ratio, $17 \%$ of the $\mathbf{N}$ fixed by alfalfa plants and $13 \%$ of that fixed by birdsfoot trefoil was transferred to the grass when grown within $1 \mathrm{~m}$.

Leyshorn et al. (1981) studied mixtures of grass and alfalfa in semiarid environments of Saskatchewan, Canada. Alfalfa plus crested wheatgrass and alfalfa plus Russian wildrye [Psathyrostachys juncea (Fisch.) Nevski] produced significantly more forage than either crested wheatgrass or Russian wildrye alone. The advantages of alfalfa in crested wheatgrass stands also were demonstrated by Rogler and Lorenz (1969). Alfalfa-crested wheatgrass mixtures were more productive than pure stands of crested wheatgrass, due not only to the productivity of the additional alfalfa but the increased vigor of the grass component as well.

Rumbaugh et al. (1982) found that fourwing saltbush [Atriplex canescens (Pursh) Nutt.], cicer milkvetch (Astragalus cicer L.), sicklepod milkvetch ( $A$. falcatus Lam.), and alfalfa significantly increased the forage yield, protein concentration, and protein yield of crested wheatgrass on a semiarid range site in central Utah. In grazing trials conducted during the winter by Gade and Provenza (1986), sheep maintained higher intake and protein levels on crested wheatgrass-shrub mixtures than on pure grass stands.

Rumbaugh and Pendery (1986) evaluated estimated gains from selection in a 100-clone alfalfa breeding population when grown alone and in association with 5 perennial grasses. They suggested that grasses and the legumes to be grown in association with them be bred concurrently and that germplasm should be screened in 
mixed stands.

Casler and Drolsom (1984) evaluated differences in forage yield among cultivars of 4 cool-season perennial grass species in pure stands and in mixtures with alfalfa. No consistent differences were found in the magnitude of heritability values between the 2 stand types and rank correlations between stand types were generally nonsignificant. They suggested that cultivars of species evaluated in their trials be evaluated in mixed stands if results are to be applied to mixed stands. Reich and Casler (1985) found that alfalfa competition tended to accentuate differences among smooth bromegrass (Bromus inermis Leyss.) genotypes for neutral detergent fiber (NDF), acid detergent fiber (ADF), and cellulose. Family by stand type interactions were nonsignificant for ADF and cellulose at most growth stages, and for NDF at the early growth stage.

Complex symbiotic and competitive relationships among diverse species in the range ecosystem must be understood if grass breeders are to make realistic genetic progress. Unfortunately, little is known regarding these relationships in semiarid environments and their potential impact on genetic responses of individual species in the plant community. In the present study, forage yield, $\mathbf{N}$ concentration, and $\mathrm{N}$ yield were determined for 50 clonal lines of crested wheatgrass when grown in monoculture and in association with alfalfa during 3 production years. Objectives were to: (1) assess the effect of stand type on genetic variances and heritability values, and (2) evaluate the genotype by stand type interactions.

\section{Materials and Methods}

Plant materials consisted of 50 clonal lines randomly selected from a breeding population of the crested wheatgrass cultivar 'Hycrest'. This cultivar was originally derived from a hybrid between an induced tetraploid form of $A$. cristatum and natural tetraploid $A$. desertorum (Asay et al. 1986). The experiment was conducted at the Utah State University Evans Experimental Farm, $2 \mathrm{~km}$ south of Logan, Utah $\left(4145^{\prime} \mathrm{N}, 11148^{\prime} \mathrm{W}\right.$, at an altitude of $1,350 \mathrm{~m}$ above sea level). Vegetative propagules, initially started in pots in the greenhouse, were transplanted in the field in mid-April 1986 as single-plant plots on $0.5 \mathrm{~m}$ centers. Plots were arranged in a split-plot design with 4 replicates. Whle plots were randomly designated as grass-alone or grass-alfalfa and the $\mathbf{5 0}$ clonal lines were randomly assigned to subplots in each whole plot. Grassalone plots were surrounded $(0.5 \mathrm{~m})$ on 4 sides by propagules of another crested wheatgrass plant. Grass plants established with alfalfa were surrounded $(0.5 \mathrm{~m})$ on each side by an alfalfa plant derived from the NC-83-1 germplasm pool.

Soil at the study site is a Nibley silty clay loam and is classified as a fine, mixed mesic aquic Argiustoll. The area was fertilized with 45 $\mathrm{kg} \mathrm{N}$ per ha in October 1985 and received no additional fertilizer or supplemental irrigation during the period of the study. Following a year of establishment, all plots were harvested at a $7-\mathrm{cm}$ stubble height twice in 1987 ( 2 June and 15 September) and once in each of the 2 subsequent years (9 June 1988 and 12 June 1989). With the exception of the second harvest in 1987, grasses were harvested at or near the bloom stage of development. An additional harvest was made each year from the alfalfa plots on 27 August 1987, 18 July 1988, and 31 July 1989.

Herbage was dried at $60^{\circ} \mathrm{C}$ for 48 hours in a forced draft and ground by Wiley mill to pass through $1-\mathrm{mm}$ screen. Dry weights were determined and expressed as $\mathrm{g}$ plant ${ }^{-1}$. Total nitrogen $(\mathrm{N})$ was determined by the Kjeldahl procedure 31-3 (Bremner and Mulvaney 1982) modified by excluding the selenium catalyst in the digestion salt. Analytical precision and accuracy were typified by $98 \%$ (C.V. $=2 \%$ ) recovery of total $N$ in the National Bureau of Standards citrus leaf sample, NBS-1572, which was analzyed with the grass samples. Nitrogen yield was determined for each plot from the forage yield and $\mathrm{N}$ data and expressed as $\mathrm{g} \mathrm{N}$ plant ${ }^{-1}$.

Data were subjected to standard analyses of variance and regression procedures. Broad-sense heritability values were computed on a mean basis as the ratio $\sigma_{\mathrm{C}}^{2} / \sigma_{\mathrm{Ph}}^{2}$, where $\sigma_{\mathrm{C}}^{2}$ is the variance component arising from differences among clonal lines, and oph is the phenotypic variance among the clonal lines or the variance of a clonal mean. In the computation of the variance components and $F$ tests, clonal lines, replications, and years were considered as random variables and stand types as fixed. Approximate $F$ tests were computed when determined necessary by evaluation of expected mean squares.

\section{Results and Discussion}

Significant $(P<0.01)$ variation was found among the 50 crested wheatgrass clonal lines in forage yield, $\mathrm{N}$ content, and $\mathrm{N}$ yield when grown with and without alfalfa during each of the 3 harvest years, and in the analyses combined over years (Tables 1,2 , and 3 ). The significance levels of the mean squares from the analyses of variance, along with the magnitude of the range in means, genetic variance, and broad-sense heritability values indicate that excellent opportunities exist to improve the genetic potential of this Hycrest breeding population to produce more and higher quality (based on crude protein) forage.

Table 1. Mean squares from analyses of variance for forage yield, nitrogen concentration, and nitrogen yield data from 50 clonal lines of crested wheatgrass grown alone and with alfalfa.

\begin{tabular}{|c|c|c|c|c|}
\hline $\begin{array}{l}\text { Source of } \\
\text { variation }\end{array}$ & 1987 & 1988 & 1989 & $1987-89$ \\
\hline $\begin{array}{l}\text { Stand type (S) } \\
\text { Clone (C) } \\
\text { S X C } \\
\text { Year (Y) } \\
\text { S X Y } \\
\text { C X Y } \\
\text { S X C X Y }\end{array}$ & $\begin{array}{c}19899 \\
5736^{* *} \\
1321\end{array}$ & $\begin{array}{r}\text { M Yield } \\
69567^{* *} \\
1866^{* *} \\
305^{* *}\end{array}$ & $\begin{array}{r}\left.\text { plant }^{-1}\right) \ldots \\
126558^{* *} \\
5269^{* *} \\
807^{* *}\end{array}$ & $\begin{array}{c}192822^{*} \\
10964^{* *} \\
1408 \\
558905^{* *} \\
11601^{*} \\
954^{* *} \\
513^{* *}\end{array}$ \\
\hline $\begin{array}{l}\text { Stand type (S) } \\
\text { Clone (C) } \\
\text { S X C } \\
\text { Year (Y) } \\
\text { S X Y } \\
\text { C X Y } \\
\text { S X C X Y }\end{array}$ & $\begin{array}{c}5380.2^{* *} \\
52.9^{* *} \\
7.6\end{array}$ & $\begin{array}{r}--\mathrm{N}(\mathrm{m} \\
525.8^{* *} \\
5.2^{* *} \\
1.5^{* *}\end{array}$ & $\begin{array}{c}849.7^{* *} \\
6.6^{* *} \\
2.6\end{array}$ & $\begin{array}{c}5244.2 \\
32.6^{* *} \\
4.5^{*} \\
6309.1^{* *} \\
755.8^{* *} \\
16.1^{* *} \\
3.6\end{array}$ \\
\hline $\begin{array}{l}\text { Stand type (S) } \\
\text { Clone (C) } \\
\text { S X C } \\
\text { Year (Y) } \\
\text { S X Y } \\
\text { C X Y } \\
\text { S X C X Y }\end{array}$ & $\begin{array}{c}136.697^{*} \\
1.832^{* *} \\
0.516\end{array}$ & $\begin{array}{c}\text { N Yield }(\mathrm{g} \\
20.207^{* *} \\
0.288^{* *} \\
0.056^{*}\end{array}$ & $\begin{array}{r}\left.\operatorname{lant}{ }^{-1}\right) \\
41.620^{* *} \\
0.769^{* *} \\
0.190^{* *}\end{array}$ & $\begin{array}{c}170.832^{*} \\
2.090^{* *} \\
0.388 \\
338.939^{* *} \\
13.846^{*} \\
0.399^{* *} \\
0.187^{*}\end{array}$ \\
\hline
\end{tabular}

*,**Significant at 0.05 and 0.01 level of probability level, respectively.

Crested wheatgrass clones grown with alfalfa produced significantly more dry matter than when grown alone during each of the 3 years and when the data were combined over years. The effect of alfalfa on DM yield of associated grass plants was particularly evident in 1988 and 1989. The clones produced $133,66,94 \mathrm{~g} \mathrm{plant}^{-1}$ in 1987,1988 , and 1989, respectively, with alfalfa compared to 119 , 39 , and $59 \mathrm{~g} \mathrm{plant}^{-1}$ when grown when without alfalfa. The smaller effect of associated alfalfa in 1987 was possibly due to the residual $\mathrm{N}$ remaining in the soil from the application made during the fall of 1985. Also, substantially more precipitation was received in 1987 than in 1988 and 1989. 
Table 2. Summary of DM yield data from 50 clonal lines of crested wheatgrass grown alone and in association with alfalfa.

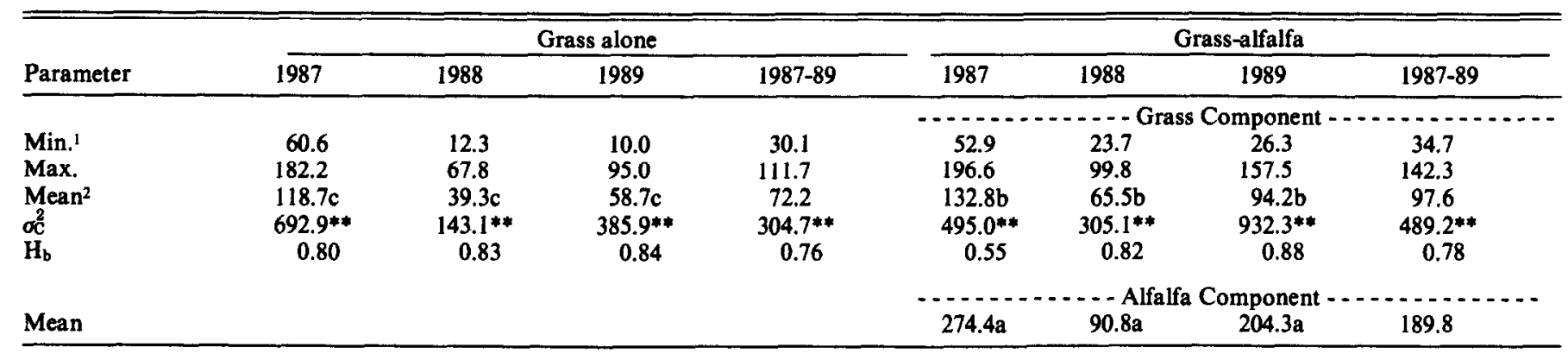

Data are expressed in $\mathrm{g} /$ plant; $\sigma_{\mathrm{C}}^{2}=$ Variance Component among clonal lines; $\mathrm{H}_{\mathrm{b}}=$ Heritability computed in the broad sense on a mean basis.

2Means for grass alone, grass component with alfalfa, and alfalfa component with grass are not significantly different within years at the 0.05 probability level when followed by the same letter. Approximate $F$ test was significant $(P<0.05)$ in analysis combined over years (1987-89).

*,***Means squares from which variance components were computed are significant at 0.05 and 0.01 probability levels, respectively.

The benefits of associated alfalfa were also reflected in concentration and yield of $\mathrm{N}$. The clonal lines had a higher $\mathrm{N}$ concentration and $\mathrm{N}$ content when grown with alfalfa than without alfalfa all 3 years (Table 3 ). In contrast to the DM yield data, the effect was at least as great in 1987 as in the 2 subsequent years. Forage of the Hycrest clones had $15.5,11.4$, and $10.5 \mathrm{mg} \mathrm{N} \mathrm{g}^{-1}$ without alfalfa in 1987,1988 , and 1989 , respectively, compared to $22.8,13.7$, and $13.4 \mathrm{mg} \mathrm{N} \mathrm{g}^{-1}$ plots with alfalfa. Similar trends were observed in nitrogen yield of the clonal lines. In the analysis combined over the 3 years (Table 1), the approximate $F$ test lacked the precision to detect statistical significant differences in $\mathrm{N}$ concentration due to stand type.

Opportunities for selection, as indicated by the genetic variances among clones and the range in clonal means, were also enhanced by the associated alfalfa plants. As was the case with mean DM yield, the positive effects of alfalfa on the genetic variance and range for DM yield was much more pronounced in 1988 and 1989 than during the first year of data collection, 1987 (Table 2). In 1988 and 1989 , the genetic variance $\left(\sigma_{\mathrm{C}}^{2}\right)$ among clones grown with alfalfa was more than twice as large as the variance among the same clones grown without alfalfa ( 305 vs 143 and 932 vs 386). The range in clonal means was also substantially greater in the grass-alfalfa plots. Forage yield of the crested clonal lines ranged from 12 to 68 and from 10 to $95 \mathrm{~g} /$ plant in 1988 and 1989 for grass alone, compared with a range of 24 to 100 and 26 to $158 \mathrm{~g}$ / plant for the grasses with alfalfa. Broad-sense heritability values for DM yield were similar for the 2 stand types and ranged from 0.55 to 0.88 .

A positive effect of associated alfalfa on the range and genetic variance for $\mathrm{N}$ concentration and $\mathrm{N}$ yield was evident during the 3 years of the study and in the combined analyses. The effect was particularly noteworthy in the analyses of the $\mathrm{N}$ yield data (Table 3). The genetic variances for $N$ yield were $0.11,0.02$, and 0.04 , and 0.04 in each of the 3 years and in the combined analysis, respectively. Comparable values for grass with alfalfa were $0.25,0.05$, 0.16 , and 0.10 . As was the case with DM yield, broad-sense heritability values were not substantially affected by the associated legume, ranging from 0.67 to 0.81 without alfalfa and from 0.56 to 0.83 in the grass with alfalfa plots. Similar trends were detected in the $\mathrm{N}$ concentration data.

The clone by stand type interaction was significant $(P<0.01)$ in the 1988 and 1989 analyses of the DM yield data, but was nonsignificant in 1987 and in the combined analysis (Table 1). This suggests that the relative productivity of individual clonal lines was somewhat inconsistent when grown alone and with alfalfa. However, annual forage yields of the clones in the 2 stand types were positively and significantly $(P<0.01,48 \mathrm{df})$ correlated in all 3 years and in the combined analysis of the data. The correlation coefficients ( $r$ ) between stand types was $0.63,0.77,0.80$, and 0.79 in 1987 , 1988,1989 , and in the combined analysis, respectively.

A similar degree of consistency was found for $\mathrm{N}$ concentration and $\mathbf{N}$ yield. Although the clone by stand type interaction was significant in 3 of the 8 instances, correlation analyses indicated that differences among the clonal lines were relatively consistent for the 2 stand types. Correlation coefficients between stand types for the data combined over years were 0.78 for $\mathrm{N}$ concentration and 0.79 for $\mathrm{N}$ yield.

Table 3. Summary of nitrogen concentration and nitrogen yield data from 50 clonal lines of crested wheatgrass grown alone and in association with alfalfa

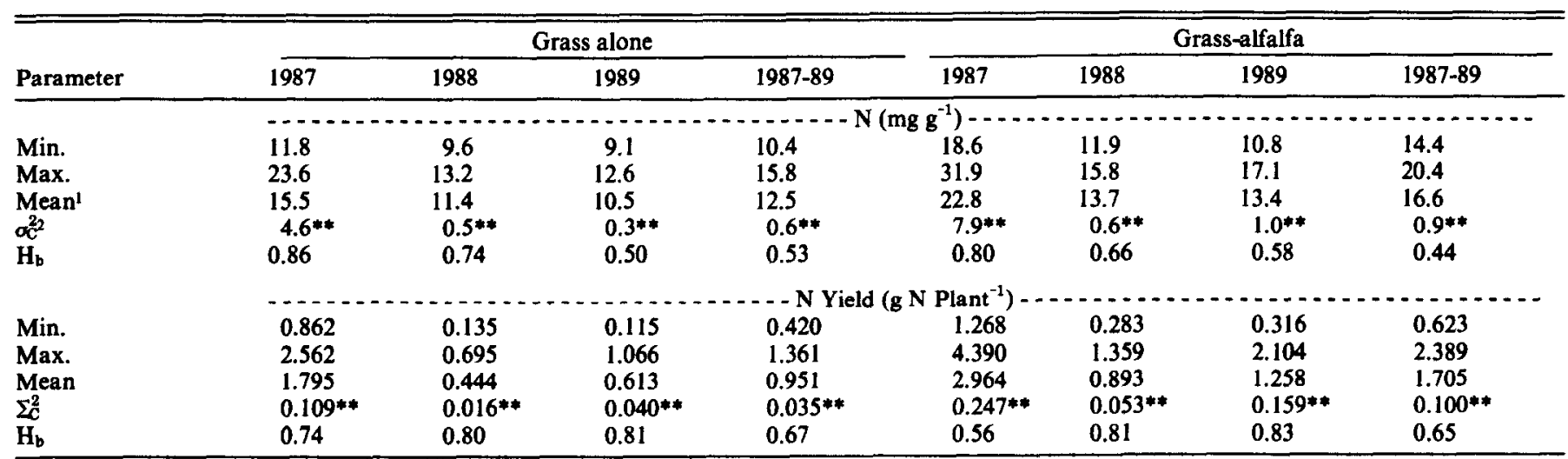

${ }^{1}$ Means for grass grown alone or with alfalfa within years and when combined over years are significantly different at the 0.05 probability level, except for $\mathrm{N}$ concentration combined over years.

${ }_{2}^{2}=$ Variance Component among clonal lines; $H_{b}=$ Heritability computed in the broad sense on a mean basis.

$*, * *$ Means squares from which variance components were computed are significant at 0.05 and 0.01 probability levels, respectively. 
Although the objective of this study was not to compare the yields of the grass and alfalfa plants in the mixture, it is noteworthy that alfalfa plants produced significantly more total forage than their grass counterparts in all 3 years (Table 2). This superiority resulted entirely from the aftermath yields of the alfalfa component in 1987 and 1988. Crested wheatgrass produced significantly $(P<0.05)$ more forage than the bordering alfalfa plants at the first harvest in 1987 (114 vs $97 \mathrm{~g} \mathrm{plant}^{-1}$ ) and the first-harvest yields of the 2 species were equivalent in 1988. In 1989, the alfalfa component $\left(148 \mathrm{~g} \mathrm{plant}^{-1}\right)$ was significantly $(P<0.01)$ more than that produced by the associated grass clones $\left(94 \mathrm{~g} \mathrm{plant}^{-1}\right.$ ).

It is evident that sufficient genetic variability remains in this breeding population of crested wheatgrass to effectively select for improved forage yield and nitrogen content. Genetic variability for these attributes was significantly increased by the association of alfalfa plants in the mixture. Higher $\mathbf{N}$ concentration in grasses grown with alfalfa indicates that the increased genetic variability resulted primarily from a more optimum environment provided by the apparent transfer of biologically fixed $\mathrm{N}$ from the associated alfalfa plants to the grass root systems. These results support earlier findings for perennial range grasses (Rumbaugh et al. 1984) and perennial humid grasses (Reich and Casler 1985). The relatively consistent performance of the grass clones across stand types is encouraging and may have been associated with autotetraploid nature of the Hycrest breeding population. Additional research would be in order to evaluate the stability of diploid populations of crested wheatgrass. Our findings indicate that initial screening for DM yield, nitrogen concentration, and nitrogen yield could be effectively done in tetraploid crested wheatgrass in plots without alfalfa. Final evaluation of breeding lines and experimental strains, however, should be done with alfalfa if the object is to develop cultivars to be grown in combination with that species.

\section{References}

Asay, K.H., D.R. Dewey, F.B. Gomm, W.H. Horton, and K.B. Jensen. 1986. Genetic progress through hybridization of induced and natural tetraploids in crested wheatgrass. J. Range Manage. 39:261-263.

Boller, B.C., and J. Nosberger. 1987. Symbiotically fixed nitrogen from field-grown white and red clover mixed with ryegrasses at low levels of ${ }^{15} \mathrm{~N}$-fertilization. Plant and Soil 104:219-226.
Bremner, J.M., and C.S. Mulvaney. 1982. Nitrogen-total. p. 595-624. In: A.L. Page (ed.). Agron. No. 9 Part 2. Amer. Soc. Agron. Publ. Madison, Wisconsin.

Brophy, L.S., and G.H. Heichel. 1989. Nitrogen release from roots of alfalfa and soybean grown in sand culture. Plant and Soil 116:77-84.

Brophy, L.S., G.H. Heichel, and M.P. Russelle. 1987. Nitrogen transfer from forage legumes to grass in a systematic planting design. Crop Sci. 27:753-758.

Casler, M.D., and P.N. Drolsom. 1984. Yield testing cool-season forage grasses in pure stands vs. binary mixtures with alfalfa. Crop Sci. $24: 453-456$

Dillman, A.C. 1946. The beginnings of crested wheatgrass in North America. J. Amer. Soc. Agron. 38:237-250.

Fred, E.B., I.L. Baldwin, and E. McCoy. 1932. Root nodule bacteria and leguminous plants. Studies in Science 5: Univ. of Wisconsin Press, Madison.

Gade, A.E., and F.D. Provenza. 1986. Nutrition of sheep grazing crested wheatgrass versus crested wheatgrass-shrub pastures during winter. J. Range Manage. 39:527-530.

Heichel, G.H. 1987. Legume nitrogen: symbiotic fixation and recovery by subsequent crops. p. 63-80. In: Helsel, Z.R. (ed.) Energy in plant nutrition and pest control. Elsevier Science Publ. B.V., Amsterdam, The Netherlands.

Leyshor, A.J., M.R. Kilcher, and J.D. McElgunn. 1981. Seeding rates and row spacings for three forage crops grown alone or in alternate grassalfalfa rows in southwestern Saskatchewan. Can. J. Plant Sci. 61:711-717.

Lohnis, F. 1926. Effect of growing legumes upon succeeding crops. Soil Sci. 22:355-389.

Reich, J.M., and M.D. Casler. 1985. Effect of maturity and alfalfa competition on expected selection response for smooth bromegrass forage quality traits. Crop Sci. 25:635-640.

Rogler, G.A., and R.L. Lorenz. 1969. Pasture productivity of crested wheatgrass as influenced by nitrogen fertilization and alfalfa. USDAARS Tech. Bull. 1402 p. 1-33.

Rumbaugh, M.D., D.A. Johnson, and G.A. Van Epps. 1982. Forage yield and quality in a Great Basin shrub, grass, and legume pasture experiment. J. Range Manage. 35:604-609.

Rumbaugh, M.D., and B.M. Pendery. 1986. Interspecific relations and the breeding of pasture plants for semiarid regions. Agron. Soc. New Zealand. p. 285-290. In: T.A. Williams and G.S. Wratt (ed.) Plant breeding symposium DSIR 1986. Spec. Pub. 5. Agron. Soc. New Zealand.

Ta, T.C., and M.A. Faris. 1987. Species variation in the fixation and transfer of nitrogen from legumes to associated grasses. Plant and Soil 98:265-274.

Ta, T.C., F.D.H. MacDowell, and M.A. Faris. 1986. Excretion of nitrogen assimilated from $\mathrm{N}_{2}$ fixed by nodulated roots of alfalfa (Medicago sativa). Can. J. Bot. 64:2063-2067.

Trenbath, B,R. 1974. Biomass productivity of mixtures. Adv. Agron. 26:177-210. 